УдК 616.37-002-036.12-06:616.345-008.87]-092

DOI 10.11603/1811-2471.2017.v0.i2.7664

\title{
STRUCTURAL CONDITION OF PANCREAS AND LIVER IN PATIENTS SUFFERING FROM CHRONIC BILIARY PANCREATITIS COMBINED WITH OBESITY
}

\section{@L. S. Babinets, K. Yu. Kytsai \\ I. Horbachevsky Ternopil State Medical University}

SUMMARY. Introduction. Statistics shows an increasing number of obese people for the past years in the world. Despite increased attention to the issue of the scientific and practical medicine, obesity is systemic and affects the metabolism and physiological parameters.

The aim of the study. Comparative analysis of indicators of liver and pancreas stiffness in patients with chronic biliary pancreatitis (CBP) depending on the degree of obesity.

Materials and Methods. 100 patients with CBP were examined; 20 young healthy people who composed the control group. BMI calculated by Quetelet index.

Results and Discussion. The level of the stiffness of liver was $(11.81 \pm 0.28) \mathrm{kPa}$, that is 2.5 times higher than in a control group, and the level of the stiffness of pancreas - in 2.0 times in patients with CBP with the obese class III. The indicator of stiffness of liver and pancreas is higher than in a control group in 2.0 and 1.8 times, respectively, in patients with obese class II and in patients with obese class I is 1.6 and 1.5 times, and in patients with overweight in 1.30 and 1.28 times.

Conclusions. According to the data, it was proved that the an increasing degree of obesity the stiffness of the liver and pancreas increases too.

KEY WORDS: chronic pancreatitis; pancreas; liver; obesity; shear wave elastograpy; structural condition.

Introduction. Statistics shows an increasing number of obese people for the past years in the world. Despite increased attention to the issue of the scientific and practical medicine, obesity is systemic and affects the metabolism and physiological parameters $[1,2]$. The risk of chronic pancreatitis for obese people is the highest with biliary and alcohol types [3]. There is a link between obesity and diseases of the biliary system.

The aim of the study. Comparative analysis of indicators of pancreas stiffness in patients with chronic biliary pancreatitis (CBP) depending on the degree of obesity.

Materials and Methods. 100 patients with CBP were examined; 20 young healthy people who composed the control group. Among patients with $\mathrm{CP}$ were 56 women and 44 men, the average age of patients was ( $49.4 \pm 3.2)$ years. The duration of the disease $-(10.8 \pm 4.1)$ years. BMI calculated by Quetelet index. Normal weight: 18.5 to 25, overweight: 25 to 30 , obese class I: 30 to 35 , obese class II: 35 to 40 , obese class III: over 40 .

Investigation of the stiffness of pancreas and liver was performed by shear wave elastography (SWE) using an ultrasound scanner Ultima PA («Radmir» DP AT NDIRI, Kharkiv, Ukraine) with a contact by sensor linear format at frequencies of 2-5 MHz at the depth of $10-50 \mathrm{~mm}$.

Results and Discussion. Results of investigation of the structural condition of liver and pancreas are presented in the table.

According to data given in the table, one could argue that an increasing degree of obesity the stiffness of the liver and pancreas increases too. The

Table. Indicators of the stiffness of liver and pancreas in patients with CBP combined with obesity

\begin{tabular}{|c|c|c|c|c|c|}
\hline \multirow{2}{*}{$\begin{array}{c}\text { Indicators of SWE of } \\
\text { the organ, } \mathrm{kPa}\end{array}$} & \multirow{2}{*}{$\begin{array}{c}\text { Control } \\
(n=20)\end{array}$} & \multicolumn{4}{|c|}{ Groups of comparison } \\
\hline & & $\begin{array}{l}\text { Overweight } \\
(n=35)\end{array}$ & $\begin{array}{c}\text { Obese class I } \\
(n=56)\end{array}$ & $\begin{array}{l}\text { Obese class II } \\
\quad(n=21)\end{array}$ & $\begin{array}{c}\text { Obese class III } \\
(n=3)\end{array}$ \\
\hline Liver & $4.80 \pm 0.24$ & $\begin{array}{l}6.22 \pm \\
0.10 *\end{array}$ & $\begin{array}{l}7.80 \pm \\
0.14^{* *}\end{array}$ & $\begin{array}{l}9.57 \pm \\
0.22 * * 1\end{array}$ & $\begin{array}{l}11.81 \pm \\
0.28^{* * 2}\end{array}$ \\
\hline Pancreas & $4.67 \pm 0.12$ & $\begin{array}{l}6.00 \pm \\
0.11^{*}\end{array}$ & $\begin{array}{l}7.13 \pm \\
0.11^{* *}\end{array}$ & $\begin{array}{l}8.60 \pm \\
0.15^{* * 1}\end{array}$ & $\begin{array}{l}9.56 \pm \\
0.37 * * 2\end{array}$ \\
\hline
\end{tabular}

Notes:

$1)^{*}$ - credible difference regarding the control group $(p<0.05)$;

$2) * *$ - credible difference regarding indicators in patients with a overweight $(p<0.05)$;

$3)^{* * 1}$ - credible difference regarding indicators in patients with obese class I $(p<0.05)$;

$4)^{* * 2}$ - credible difference regarding indicators in patients with obese class II $(p<0.05)$. 
Огляди літератури, оригінальні дослідження, погляд на проблему, короткі повідомлення

level of the stiffness of liver was $(11.81 \pm 0.28) \mathrm{kPa}$ that is 2.5 times higher than in a control group, and the level of the stiffness of pancreas - in 2.0 times in patients with CBP with the obese class III. The indicator of the stiffness of liver and pancreas is higher than in a control group in 2.0 and 1.8 times, respectively, in patients with obese class II and in patients with obese class I is 1.6 and 1.5 times, and in patients with a overweight in 1.30 and 1.28 times. Data were statistically significant.

Conclusions. According to the data, it has been proved that the an increasing degree of obesity the stiffness of the liver and pancreas increases too. It showed the progression of fibrotic processes in the parenchyma of the above mentioned bodies with pathological changes in their structure.

\section{ЛІТЕРАТУРА}

1. Радченко О.М. Підшлункова залоза та метаболічний синдром / О. М. Радченко // Сучасна гастроентерологія. -2013. - № 5 (73). - Р. 21-26.

2. Pitt H. A. (2007). Hepato-pancreato-biliary fat: the good, the badand the ugly / H. A. Pitt // HPB. - № 9. - P. 92-97.

\section{REFERENCES}

1. Radchenko, O.M. (2013). Pidshlunkova zaloza ta metabolichnyi syndrom [Pancreas and metabolic syndrome]. Suchasna hastroenterolohiya - Modern Gastroenterology, 5 (73), 21-26 [in Ukrainian].

2. Pitt, H.A. (2007). Hepato-pancreato-biliary fat: the

good, the badand the ugly. $H P B, 9,92-97$.

3. Van Raalte, D.H, Van der Zijl, N.J., \& Diamant, M. (2010). Pancreatic steatosis in humans: cause or marker of lipotoxicity? Curr. Opin. Clin. Nutr. Metab. Care, 13, 478-485.

\section{СТРУКТУРНИЙ СТАН ПІДШЛУНКОВОЇ ЗАЛОЗИ І ПЕЧІНКИ У ПАЦІЄНТІВ, ХВОРИХ НА

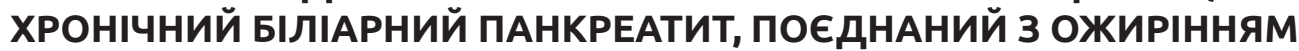

3. Van Raalte D. H. (2010). Pancreatic steatosis in humans: cause or marker of lipotoxicity? / D. H. Van Raalte, N. J. Van der Zijl, M. Diamant // Curr. Opin. Clin. Nutr. Metab. Care. - № 13. - 478-485.

\section{๑Л. С. Бабінець, К. Ю. Кицай}

ДВНз «Тернопільський державний медичний університет імені І. Я. Горбачевського мОз України»

РЕЗЮМЕ. Вступ. Статистика свідчить про зростання кількості огрядних людей протягом останніх років у цілому світі, незважаючи на підвищену увагу до цієї проблеми з боку наукової і практичної медицини. Ожиріння має системний характер і впливає на метаболізм та фізіологічні параметри.

Мета - проведення порівняльного аналізу показників жорсткості підшлункової залози та печінки у хворих на хронічний біліарний панкреатит (ХБП) в залежності від ступеня ожиріння.

Матеріал та методи. Було обстежено 100 пацієнтів з ХП біліарного ґенезу. Групу контролю склали 20 молодих здорових людей. ІМТ обчислювали за формулою Кетле.

Результати. У пацієнтів, хворих на ХБП, які мали III ступінь ожиріння, рівень жорсткості печінки становив $(11,81 \pm 0,28)$ кПа, що у 2,5 раза перевищувало такий групи контролю, а показник жорсткості П3 - у 2,0 рази. Показник жорсткості печінки і ПЗ у групі хворих із ІІ ступенем ожиріння перевищував такий групи контролю у 2,0 і 1,8 раза відповідно, а у пацієнтів з І ступенем - в 1,6 та 1,5 раза і у хворих з надмірною масою тіла - у 1,30 та 1,28 раза.

Висновки. У хворих на хронічний біліарний панкреатит в поєднанні з ожирінням із зростанням маси тіла збільшуються показники жорсткості як печінки, так і підшлункової залози.

КлючОВІ СЛОВА: хронічний панкреатит; підшлункова залоза; печінка; ожиріння; еластографія хвилі зсуву; структурний стан. 
Огляди літератури, оригінальні дослідження, погляд на проблему, короткі повідомлення

СТРУКТУРНОЕ СОСТОЯНИЕ ПОДЖЕЛУДОЧНОЙ ЖЕЛЕЗЫ И ПЕЧЕНИ ПАЦИЕНТОВ, СТРАДАЮЩИХ ХРОНИЧЕСКИМ БИЛИАРНЫМ ПАНКРЕАТИТОМ, СОВМЕЩЕННЫМ С ОЖИРЕНИЕМ

\section{○Л. С. Бабинец, Е. Ю. Кыцай}

ГВНЗ «Тернопольский государственный медицинский университет имени И. Я. Горбачевского МОЗ Украины»

РЕЗЮМЕ. Вступление. Статистика свидетельствует о росте количества тучных людей в последние годы во всем мире, несмотря на повышенное внимание к этой проблеме со стороны научной и практической медицины. Ожирение имеет системный характер и влияет на метаболизм и физиологические параметры.

Цель - проведение сравнительного анализа показателей жесткости поджелудочной железы и печени у больных хроническим билиарным панкреатитом (ХБП) в зависимости от степени ожирения.

Материал и методы. Было обследовано 100 пациентов с ХП билиарного генеза. Группу контроля составили 20 молодых здоровых людей. ИМТ вычисляли по формуле Кетле.

Результаты. У пациентов, больных ХБП, с ІІІ степенью ожирения уровень жесткости печени составил $(11,81 \pm 0,28)$ кПа, что в 2,5 раза превышало такой группы контроля, а показатель жесткости Пж - в 2,0 раза. Показатель жесткости печени и Пж в группе больных с II степенью ожирения превышал такой группы контроля в 2,0 и 1,8 раза соответственно, а у пациентов с I степенью - в 1,6 и 1,5 раза и у больных с чрезмерной массой тела - в 1,30 и 1,28 раза.

Выводы. У больных хроническим билиарным панкреатом в сочетании с ожирением с ростом массы тела увеличивались показатели жесткости как печени, так и поджелудочной железы.

КЛЮчЕВЫЕ СЛОВА: хронический панкреатит; поджелудочная железа; печень; ожирение; эластография волны сдвига; структурное состояние. 